\title{
Geniposide, a component of Gardenia jasminoides Ellis, inhibits NF-KB to attenuate LPS-induced injury in intestinal epithelial cells
}

Yizhe Cui ( $\sim$ cuiyizhe1979@126.com )

Heilongjiang Bayi Agricultural University https://orcid.org/0000-0002-7877-8328

\section{Xinyue Qiao}

Heilongjiang Bayi Agricultural University

Qiuju Wang

Heilongjiang Bayi Agricultural University

Rui Wu

Heilongjiang Bayi Agricultural University

Research article

Keywords: Geniposide, NF-kB, IEC-6, Signaling pathway, Cell migration

Posted Date: March 18th, 2020

DOI: https://doi.org/10.21203/rs.3.rs-17588/v1

License: (1) This work is licensed under a Creative Commons Attribution 4.0 International License.

Read Full License 


\section{Abstract}

Background: The nuclear factor-KB (NF-kB) transcriptional system is a major effector pathway involved in inflammatory responses. Previous studies found that a Gardenia decoction (GD) inhibited the expression of NF-KB in a lipopolysaccharide (LPS)-stimulated mouse intestinal injury model. Herein, we hypothesized that geniposide (GE), a component of Gardenia jasminoides Ellis, also exerts anti-inflammatory effects and inhibits NF-KB activity in LPS-induced intestinal epithelial cells (IEC-6). IEC-6 cells were stimulated with LPS, following which the effects of GE on NF-KB signaling in the IEC- 6 cells were examined by western blotting to detect IKB phosphorylation/degradation. The expression of NF-KB was determined by immunofluorescence assay (IFA). Enzyme-linked immunosorbent assay (ELISA) was used to detect the inhibitory effect of GE on the release of tumor necrosis factor-a (TNF- $a$ ), interleukin- 6 (IL-6) and interleukin-1 $\beta$ (IL-1 $\beta$ ) activated by LPS in IEC- 6 cells. In addition, the migration ability of IEC- 6 cells was observed by the scratch method.

Results: These results showed that GE dose-dependently downregulated levels of the proinflammatory cytokines TNF- $a$, IL- 6 and IL-1 $\beta$ that had been upregulated by LPS and suppressed the phosphorylation of IKB and NF-KB induced by LPS. Our findings indicated that GE could reduce LPS-induced NF-KB signaling and proinflammatory expression in IEC- 6 cells and significantly enhance the migration of IEC- 6 cells. Moreover, GE inhibited the expression of NF-KB, nuclear transfer, and transcriptional activity in IEC-6 cells.

Conclusion: GE could block the synthesis of inflammatory factors of IEC- 6 cells by inhibiting activation of the IKB/NF-KB signaling pathway induced by LPS.

\section{Background}

The nuclear factor-KB (NF-kB) family is a group of nuclear protein factors that regulate the expression of a wide range of genes. These nuclear protein factors play an important role in regulating the transcription of genes related to inflammation; cell proliferation, differentiation and apoptosis; the immune response; and tumorigenesis. In most cells, NF-KB proteins can form homodimers or heterodimers that bind IKBs in an inactive state in the cytoplasm. When stimulated by stimulants such as viruses, radiation, oxygen free radicals, bacterial lipopolysaccharide (LPS) and tumor necrosis factor- $\mathrm{a}$ (TNF-a), the NF-KB-IKBs complex is activated, NF-KB is released and transferred to the nucleus, and its binding at specific sites promotes transcription of the corresponding genes, thus initiating and regulating the immune response, cell adhesion, differentiation, proliferation, apoptosis and inflammation.

Expression of the NF-KB promoter gene involves the activation of IKK, phosphorylation and ubiquitination of IKB, cleavage of IKB, migration of NF-KB to the nucleus, and binding of NF-kB to DNA. Overactivation of NF-KB can lead to a series of diseases, including asthma, rheumatoid arthritis, enteritis and so on. Inhibiting signal transduction pathways with a core of NF-KB through drugs or gene transformation may be an effective way to prevent and treat some diseases. Some traditional Chinese medicine extracts, such as flavonoids [1] and steroid-like compounds [2], can strongly block IKK activity, thus inhibiting the 
phosphorylation and degradation of IKB and blocking the activity and protein-binding ability of NF-KB. These compounds have advantages in the treatment of some inflammatory diseases.

In previous studies, we found that Gardenia decoction (GD) markedly inhibited inflammatory cytokine production and reduced the expression of NF-KB following LPS stimulation in vivo [3]. Geniposide (GE), the main active ingredient of Gardenia jasminoides, is a kind of iridoid terpenoid glucoside [4]. Modern studies have shown that GE has substantial effects on digestive system, cardiovascular system and central nervous system diseases. In addition, GE has certain anti-inflammatory and therapeutic effects on soft tissue injury. However, the mechanism through which GE mediates its anti-inflammatory effects is not completely understood.

In this study, we investigated the role of GE in protection against LPS using in vitro cultured IEC- 6 cells. Our results showed that GE exerts an anti-inflammatory effect and that GE blocks the activation of NF-KB signaling by targeting IKB in IEC-6 cells in vitro.

\section{Methods}

\section{Reagents}

GE (purity > 98\% SG8100) was purchased from Solarbio Co. (Beijing, China). LPS (Escherichia coli 055: B5) was obtained from Sigma Chemical Co. (St. Louis, MO, USA). G. jasminoides Ellis extract was obtained according to a previous method [3] with slight modifications. In the previous experiment, we determined the composition and content of G. jasminoides Ellis extract by LC/MS Analysis. Briefly, the mixture was filtered through a 100-mesh metal sieve. The filtrate (crude decoction) was sterilized using a $0.22-\mu \mathrm{m}$ syringe filter for cell processing. The extract of GD was identified by Qingdao Kechuang Quality Inspection Co., Ltd. (Qingdao, China). (Application No. PDFD-16-01 D/0). The specimen has been disposed in the laboratory of animal pharmacy, Heilongjiang Bayi Agricultural University

\section{Cell culture and viability assay}

Intestinal epithelial cells (IEC-6 cells) were obtained from the Institute of Basic Medicine, Chinese Academy of Medical Sciences (Beijing, China) and cultured in Roswell Park Memorial Institute (RPMI) 1640 medium supplemented with $10 \%$ fetal bovine serum (FBS), antibiotics $\left(0.1 \mathrm{mg} \cdot \mathrm{mL}^{-1}\right.$ streptomycin and $100 \mathrm{U} \cdot \mathrm{mL}^{-1}$ penicillin) and $10 \mu \mathrm{g} \cdot \mathrm{mL}^{-1}$ bovine insulin. Cells were maintained at $37^{\circ} \mathrm{C}$ in a $5 \% \mathrm{CO}_{2}$ atmosphere. After $24 \mathrm{~h}$, the cells were harvested, plated on 96-well plates at a density of 5,000 cells/well and then treated with LPS, GE and GD at different concentrations. After $24 \mathrm{~h}$ of incubation, $20 \mu \mathrm{L}$ of MTT $(5 \mathrm{mg} / \mathrm{mL})$ was added to each well, and the cells were incubated for $4 \mathrm{~h}$ at $37^{\circ} \mathrm{C}$. The medium was replaced with $100 \mathrm{~mL}$ of dimethyl sulfoxide (DMSO), and the cells were incubated for 5 min while shaking. Cellular viability was determined by measuring the optical density (OD) at $490 \mathrm{~nm}$ with a spectrophotometer.

\section{Cell treatment}


IEC- 6 cells were cultured in 96 -well plates at a density of $5 \times 10^{3}$ cells/well. The cells were divided into a normal control group, LPS model group, GD treatment group (treated with different concentrations of GD) and GE treatment group (treated with different concentrations of GE). After pretreatment with GD and GE for $24 \mathrm{~h}$, LPS was added to the cell culture for $12 \mathrm{~h}$. Cells were then collected for subsequent testing.

\section{Cell migration assays}

The IEC- 6 cells were seeded into 12 -well cell culture plates for $24 \mathrm{~h}$ at $37^{\circ} \mathrm{C}$ in a humidified atmosphere containing $5 \% \mathrm{CO} 2$, at a concentration of $5 \times 10^{3}$ cells $/ \mathrm{mL}$, and cultured in a medium containing $10 \% \mathrm{FBS}$ to produce a nearly confluent cell monolayer. A linear wound was subsequently generated in the monolayer using a cutting knife in the monolayer, a scratch was made and the cell scraped off the other side. Any cellular debris was removed by washing the wells with PBS. Place the dish in a tissue culture incubator at $37^{\circ} \mathrm{C}$ for $12 \mathrm{~h}$. After incubation, the dish was placed under a phase-contrast microscope, the photographed region was aligned, and images were acquired. The acquired images of each sample were further quantitatively analyzed with computational software. The number of cells across each scratch was then determined using Image-Pro Plus software.

\section{Enzyme-linked immunosorbent assay (ELISA)}

Levels of the proinflammatory cytokines TNF-a, interleukin-6 (IL-6) and interleukin-1 $\beta$ (IL-1 $\beta$ ) were tested using specific ELISA kits (eBioscience) following the operation manual of the manufacturer.

\section{Western blot analysis}

In $10 \%$ sodium dodecyl sulfate polyacrylamide gels a total of $40 \mu \mathrm{g}$ of protein was electrophoresed. After electrophoresis, the proteins were transferred to a PVDF membrane. The membrane was soaked in a solution containing $5 \%$ bovine serum albumin and primary antibodies against NF-KB p65 (Abcam, ab32536, 1:5000), p-NF-кB p65 (\#3033, 1:1000), ІкB-a (\#2859, 1:1000), p-ІкB-a (\#4812, 1:1000) (CST, Beverly, MA, USA) and $\beta$-actin (1:1,000) (Proteintech Group, Inc., Beverly, Chicago, USA, 60008-1-ig) overnight at $4{ }^{\circ} \mathrm{C}$. The membrane was immersed in the corresponding secondary antibody diluted 1:5000 for $1 \mathrm{~h}$ in the dark at $37^{\circ} \mathrm{C}$ to enhance chemiluminescence detection of the protein. Protein density was quantified by means of imaging software.

\section{Immunofluorescence assay (IFA)}

Cells $\left(1 \times 10^{4}\right)$ were seeded on coverslips and treated with both digests then IEC- 6 cells were washed twice with PBS, fixed with $4 \%$ formaldehyde in PBS for 10 min, and permeabilized with $0.2 \%$ Triton X-100 in PBS for $5 \mathrm{~min}$ at $20^{\circ} \mathrm{C}$. The IEC- 6 cells were blocked with $5 \%$ BSA in PBS for $1 \mathrm{~h}$ at $20^{\circ} \mathrm{C}$ and then immunostained with anti-NF-KB p65 primary antibody (Abcam, ab32536, 1:1000) and secondary antibody bound to FITC (A0568, 1:500, Beyotime) overnight at $4{ }^{\circ} \mathrm{C}$. Then, the nucleus subjected to DAPI counterstaining. The NF-kB p65 proteins were observed under an Olympus IX71 fluorescence microscope.

\section{Statistical analysis}


Data are expressed as the means \pm SDs and were analyzed by one-way ANOVA. The mean separation was assessed by Tukey's multiple comparison tests (GraphPad Prism version 5 software). Differences with $\mathrm{P}<0.05$ were considered statistically significant.

\section{Results}

\section{MTT assays}

The chemical structure of GE is shown in Fig. 1A [3]. The results of MTT assays showed that the activity of IEC- 6 cells treated with GD and GE alone was not significantly different with than of IEC- 6 cells in the normal control group $(P>0.05)$ (Fig. 1B, C); however, $25 \mu \mathrm{g} / \mathrm{mL}$ LPS significantly inhibited the activity of IEC-6 cells $(P<0.01)$ (Fig. 1D). Therefore, LPS with concentration of $10 \mu \mathrm{g} / \mathrm{mL}$ was selected to prepare IEC-6 cells induce model.

\section{GE promoted the migration of IEC-6 cell in vitro}

The effect of GE on cell migration after injury is shown in Fig. 2. Treatment with GD $(100 \mu \mathrm{g} / \mathrm{mL})$ or GE $(100 \mu \mathrm{M})$ remarkably promoted cell migration compared to that in the normal control group $(P<0.01$, Fig. 2A, B). The LPS-induced injury of IEC- 6 cells significantly inhibited cell migration, and the migration rate in the LPS group at $12 \mathrm{~h}$ decreased to $64 \%$ of that of the control group (Fig. 2).

\section{GE inhibited inflammatory cytokine production in IEC-6 cells stimulated by LPS}

We measured the effect of GD and GE on levels of the inflammatory cytokines TNF- $a$, IL- 6 and IL-1 $\beta$ using ELISAs. A significant increase in the levels of TNF- $a$, IL- 6 and IL- $1 \beta$ in IEC- 6 cells induced by LPS treatment was detected compared with their levels in the control group $(P<0.01)$. Compared with LPS model group, the expression of inflammatory cytokines in GD group was significantly lower (Fig. 3A). Furthermore a significant dose-dependent decrease in inflammatory cytokine production in the GE treatment group compared with the LPS model group (Fig. 3B) $(P<0.01)$.

\section{GE inhibited the NF-KB / IKB-a proteins pathway IEC-6 cells}

As can be seen from Fig. 4, Compared with the normal control group, LPS significantly activated the phosphorylation of p-NF-kB p65 and p-IKB-a protein ( $<<0.01$ ), while GD (Fig. 4A) inhibited the phosphorylation of p-NF-KB p65 and p-IKB-a protein induced by LPS. The effect of GE on p-NF-KB p65 and p-IKB-a protein was consistent with the trend of GD (Fig. 4B).

\section{GE inhibited the LPS-induced translocation of NF-KB in IEC- 6 cells}


As shown in Fig. 5, NF-KB was obviously retained in the cytoplasm of IEC-6 cells in the normal control group. The translocation of NF-KB to the nucleus was increased, and the immunostaining signal in the cytoplasm after LPS stimulation was weaker than that in the normal control group (Fig. 5). However, treatment with GE $(100 \mu \mathrm{m})$ prevented the effects of LPS on nuclear NF-kB translocation.

\section{Discussion}

GE, a bioactive iridoid glucoside derived from $\mathrm{G}$. jasminoides, has anti-inflammatory effects [5]. In sepsis model mice, GE directly bound LPS and neutralized LPS in vitro, and significantly protecting against sepsis [6]. Gardenia, a plant belonging to the Rubiaceae family, contains various iridoid glycosides, which are unstable, nonvolatile, thermally labile, polar natural compounds [7]. The fruit of $\mathrm{G}$. jasminoides Ellis (gardenia fruit) is an Asian folk medicine that has been widely used for centuries for the treatment of inflammation, jaundice, headache [8], edema, fever, hepatic disorders [9] and hypertension [10]. The iridoid compounds GE and genipin were found to be the anti-inflammatory components of gardenia fruit. Both GE and genipin have anti-inflammatory activities, as shown via their inhibition of exudate and nitric oxide (NO) production in a carrageenan-induced rat paw edema model. Genipin suppressed both NO production and cyclooxygenase expression at an early stage and exhibited stronger anti-inflammatory activity than GE [11]. Genipin-mediated inhibition of NO production has been associated with the inhibition of NF-KB activation [12]. However, the material basis of the anti-inflammatory activity gardenia fruit is not completely clear.

In this study, we investigated the impact of GE on LPS signaling in IEC- 6 cells and elucidated its mechanism of action.

Activation of the NF-KB signaling pathway can induce expression of the proinflammatory cytokines IL- 6 [13], TNF- $\alpha$, and IL-1 $\beta$ [14], and these proinflammatory factors can further activate NF-KB, thus aggravating inflammation [15]. IL-6, TNF- $\alpha$ and IL-1 $\beta$ are important cytokines secreted by cells used to evaluate the inflammatory response. The secretion of IL-6, TNF- $\alpha$ and IL-1 $\beta$ is significantly increased in inflammatory cells $[16,17]$. Much evidence indicates that LPS-induced inflammation is closely related to increased secretion of the inflammatory factors IL-6, TNF- $\alpha$ [18] and IL-1 $\beta$ [19]. Therefore, we detected the levels of IL-6, TNF- $\alpha$ and IL-1 $\beta$ in IEC- 6 cells treated with LPS to observe the effects of LPS-induced inflammation.

In this study, LPS induction was used to establish a model of inflammation in IEC- 6 cells. LPS treatment increased IL-6, TNF- $\alpha$ and IL- $1 \beta$ secretion by IEC- 6 cells and thus upregulated inflammation in IEC- 6 cells. We found that GE at a certain concentration could downregulated the expression levels of IL-6, TNF- $a$ and L-1 $\beta$ in LPS-damaged IEC- 6 cells. Therefore, we speculated that GE at this concentration can effectively regulate the expression levels of IL-6, IL-1 $\beta$ and TNF- $\alpha$ through the IKB/NF-KB signaling pathway to further control the occurrence of inflammatory reactions.

$\mathrm{NF}-\mathrm{KB}$ is an important transcription factor that regulates the inflammatory response. At reset, NF-KB binds its inhibitor, IKB, and has no biological activity [20]. When cells are stimulated by LPS, IKB-mediated 
inhibition of NF-KB is relieved, and the NF-KB complex is dissociated and transferred to cells. After binding the corresponding site on specific DNA, it can induce the transcription of related genes and promote the release of cytokines, thus generating a systemic inflammatory response [21]. The research shows that GD could reduce the level of inflammatory cytokines in the injury model and had antiinflammatory effects on tissues [3]. However, the treatment of LPS-induced IEC-6 cells with GE has not been investigated. Western blot analysis showed that the protein expression of $\mathrm{p}-\mathrm{IKB}$ - $\mathrm{a}$ was increased, and the distribution of p-NF-KB p65 was significantly increased in IEC- 6 cells stimulated by LPS. GE prevented activation of the NF-KB pathway and decreased the nuclear transfer of p-NF-KB p65 in cells induced by LPS (Fig. 6).

Cell migration plays an important role in the repair of intestinal mucosal injury. IEC- 6 cells have been widely used in the study of intestinal mucosal repair [22]. Scholars have conducted in-depth and systematic research on the physiological regulation [23], signaling pathways [24] and pathology [25] of intestinal mucosal injury, but there have been few reports of drugs to repair the gastrointestinal mucosa. This study demonstrated that GE can promote the migration of IEC- 6 cells and reduce LPS-induced damage and has a protective effect on IEC-6 cells.

\section{Conclusion}

GE, a component of $\mathrm{G}$. jasminoides Ellis, can block the synthesis of inflammatory factors by inhibiting activation of the IKB/NF-KB signaling pathway induced by LPS, thus effectively inhibiting inflammatory damage to IEC-6 cells induced by LPS.

\section{Abbreviations}

NF-kB: nuclear factor-KB; GD: Gardenia decoction; LPS: lipopolysaccharide; GE: geniposide; IEC-6: intestinal epithelial cells; IFA: immunofluorescence assay; ELISA: Enzyme-linked immunosorbent assay; TNF-a: tumor necrosis factor-a; IL-6: interleukin-6; IL-1ß: interleukin-1 $\beta$.

\section{Declarations}

\section{Ethics approval and consent to participate}

All the experimental procedures were approved by, and conducted in accordance with Principles of Laboratory Animal Care and according to the rules and ethics set forth by the Ethical Committee of Heilongjiang Bayi Agricultural University.

\section{Consent for publication}

Not applicable.

\section{Availability of data and materials}


All the data obtained and materials analyzed in this research are available with the corresponding author.

\section{Competing interests}

The authors declare that they have no competing interests

\section{Funding}

This work was supported by the China Postdoctoral Science Foundation [grant numbers 2017M620124; 2018T110320], the Doctoral Program Foundation of Heilongjiang Bayi Agricultural University of China [grant number XDB-2016-10], the Postdoctoral Program Foundation of Heilongjiang Bayi Agricultural University [grant number 601038] and the Heilongjiang Bayi Agricultural University Support Program for San Heng San Zong (ZRCLG201904).

\section{Authors' Contribution}

YZC and XYQ conducted most of the experiments and the data analysis; QJW and YZC contributed to the discussion; RW supervised the project; and $Y Z C$ and $X Y Q$ wrote the manuscript. All authors read and approved the final manuscript.

\section{Acknowledgements}

Not Applicable.

\section{References}

1.

Kim JS, Jobin C. The flavonoid luteolin prevents lipopolysaccharide-induced NF-kappaB signalling and gene expression by blocking IkappaB kinase activity in intestinal epithelial cells and bone-marrow derived dendritic cells. Immunology. 2005;115(3):375-87.

2 .

Cheon JH, Kim JS, Kim JM, Kim N, Jung HC, Song IS. Plant sterol guggulsterone inhibits nuclear factorkappaB signaling in intestinal epithelial cells by blocking IkappaB kinase and ameliorates acute murine colitis. Inflamm Bowel Dis. 2006;12(12):1152-61.

3.

Cui Y, Wang Q, Wang M, Jia J, Wu R. Gardenia Decoction Prevent Intestinal Mucosal Injury by Inhibiting Pro-inflammatory Cytokines and NF-kappaB Signaling. Front Pharmacol. 2019;10:180.

4.

Yang SQ, Chen YD, Li H, Hui X, Gao WY. Geniposide and Gentiopicroside Suppress Hepatic Gluconeogenesis via Regulation of AKT-FOXO1 Pathway. Arch Med Res. 2018;49(5):314-22.

5.

Hu Y, Liu X, Xia Q, Yin T, Bai C, Wang Z, Du L, Li X, Wang W, Sun L, et al. Comparative anti-arthritic investigation of iridoid glycosides and crocetin derivatives from Gardenia jasminoides Ellis in Freund's 
complete adjuvant-induced arthritis in rats. Phytomedicine: international journal of phytotherapy phytopharmacology. 2019;53:223-33.

6.

Zheng X, Yang D, Liu X, Wang N, Li B, Cao H, Lu Y, Wei G, Zhou H, Zheng J. Identification of a new antiLPS agent, geniposide, from Gardenia jasminoides Ellis, and its ability of direct binding and neutralization of lipopolysaccharide in vitro and in vivo. Int Immunopharmacol. 2010;10(10):1209-19.

7.

Shang YF, Zhang YG, Cao H, Ma YL, Wei ZJ. Comparative study of chemical compositions and antioxidant activities of Zhizi fruit extracts from different regions. Heliyon. 2019;5(12):e02853. 8.

Yuan J, Zhang J, Cao J, Wang G, Bai H. Geniposide Alleviates Traumatic Brain Injury in Rats Via AntiInflammatory Effect and MAPK/NF-kB Inhibition. Cellular and molecular neurobiology 2019. 9.

Wei J, Man Q, Ding C, Hu Y, Liu M, Li H, Guo F, Zhang Y, Li D, Song L, et al. Proteomic Investigations of Transcription Factors Critical in Geniposide-Mediated Suppression of Alcoholic Steatosis and in Overdose-Induced Hepatotoxicity on Liver in Rats. J Proteome Res. 2019;18(11):3821-30. 10.

Neri-Numa IA, DellaTorre A, Oriani VB, Franch GC Jr, Angolini CFF, Dupas Hubinger M, Ruiz A, Pastore GM. In vitro bioactivity approach of unripe genipap (Genipa americana L., Rubiaceae) fruit extract and its solid lipid microparticle. Food research international. 2020;127:108720.

11.

Koo HJ, Lim KH, Jung HJ, Park EH. Anti-inflammatory evaluation of gardenia extract, geniposide and genipin. J Ethnopharmacol. 2006;103(3):496-500.

12.

Koo HJ, Song YS, Kim HJ, Lee YH, Hong SM, Kim SJ, Kim BC, Jin C, Lim CJ, Park EH. Antiinflammatory effects of genipin, an active principle of gardenia. Eur J Pharmacol. 2004;495(2-3):201-8. 13.

Dong N, Li X, Xue C, Zhang L, Wang C, Xu X, Shan A. Astragalus polysaccharides alleviates LPS-induced inflammation via the NF-kappaB/MAPK signaling pathway. Journal of cellular physiology 2020. 14.

Zusso M, Lunardi V, Franceschini D, Pagetta A, Lo R, Stifani S, Frigo AC, Giusti P, Moro S. Ciprofloxacin and levofloxacin attenuate microglia inflammatory response via TLR4/NF-kB pathway. J Neuroinflamm. 2019;16(1):148.

15.

Zhang J, Huang J, Gu Y, Xue M, Qian F, Wang B, Yang W, Yu H, Wang Q, Guo X, et al: Inflammationinduced inhibition of chaperone-mediated autophagy maintains the immunosuppressive function of murine mesenchymal stromal cells. Cellular \& molecular immunology 2020.

16.

Pedersen BK. Anti-inflammatory effects of exercise: role in diabetes and cardiovascular disease. Eur $\mathrm{J}$ Clin Invest. 2017;47(8):600-11. 
17.

Silva JF, Olivon VC, Mestriner F, Zanotto CZ, Ferreira RG, Ferreira NS, Silva CAA, Luiz JPM, Alves JV, Fazan $\mathrm{R}$, et al. Acute Increase in O-GIcNAc Improves Survival in Mice With LPS-Induced Systemic Inflammatory Response Syndrome. Frontiers in physiology. 2019;10:1614.

18.

Zhuang S, Zhong J, Zhou Q, Zhong Y, Liu P, Liu Z. Rhein protects against barrier disruption and inhibits inflammation in intestinal epithelial cells. Int Immunopharmacol. 2019;71:321-7.

19.

Antica M, Kusic B, Hranilovic D, Dietz AB, Vuk-Pavlovic S. Cloning the cDNA for murine U2 snRNP-A' gene and its differential expression in lymphocyte development. Immunology letters. 2002;82(3):217-23. 20.

Yang L, Song Z, Wang X, Yang W, Wang M, Liu H. Huaier extract enhances the treatment efficacy of paclitaxel in breast cancer cells via the NF-kappaB/lkappaBalpha pathway. Oncol Rep. 2017;38(6):345564.

21.

He J, Li J, Liu H, Yang Z, Zhou F, Wei T, Dong Y, Xue H, Tang L, Liu M. Scandoside Exerts AntiInflammatory Effect Via Suppressing NF-kappaB and MAPK Signaling Pathways in LPS-Induced RAW 264.7 Macrophages. International journal of molecular sciences 2018, 19(2).

22.

Jeong SJ, Choi JW, Lee MK, Choi YH, Nam TJ. Spirulina Crude Protein Promotes the Migration and Proliferation in IEC-6 Cells by Activating EGFR/MAPK Signaling Pathway. Marine drugs 2019, 17(4). 23.

Shi Y, Zhu H, Li R, Wang D, Zhu Y, Hu L, Chen W. Effect of polysaccharides from Sijunzi decoction on $\mathrm{Ca}(2+)$ related regulators during intestinal mucosal restitution. Phytomedicine: international journal of phytotherapy phytopharmacology. 2019;58:152880.

24.

Predes D, Oliveira LFS, Ferreira LSS, Maia LA, Delou JMA, Faletti A, Oliveira I, Amado NG, Reis AH, Fraga CAM, et al: The Chalcone Lonchocarpin Inhibits Wnt/beta-Catenin Signaling and Suppresses Colorectal Cancer Proliferation. Cancers 2019, 11(12).

25.

Ji AL, Li T, Zu G, Feng DC, Li Y, Wang GZ, Yao JH, Tian XF. Ubiquitin-specific protease 22 enhances intestinal cell proliferation and tissue regeneration after intestinal ischemia reperfusion injury. World journal of gastroenterology. 2019;25(7):824-36.

\section{Figures}


A

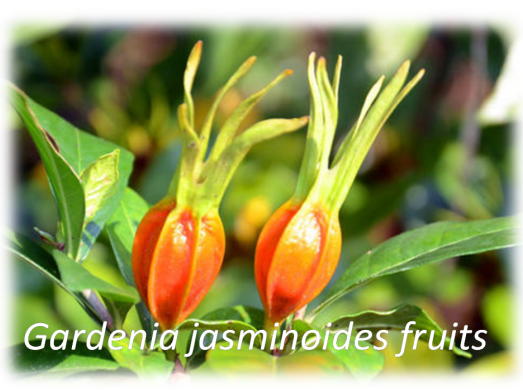

Gardenia jasminoides Ellis

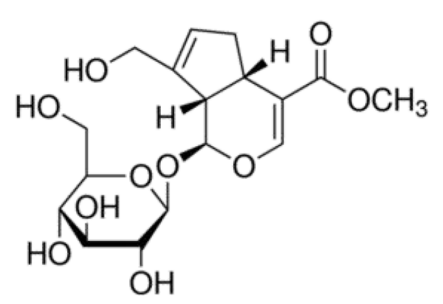

Geniposide (GE)

MF: $\mathrm{C}_{17} \mathrm{H}_{24} \mathrm{O}_{10}$

MW: 388.37
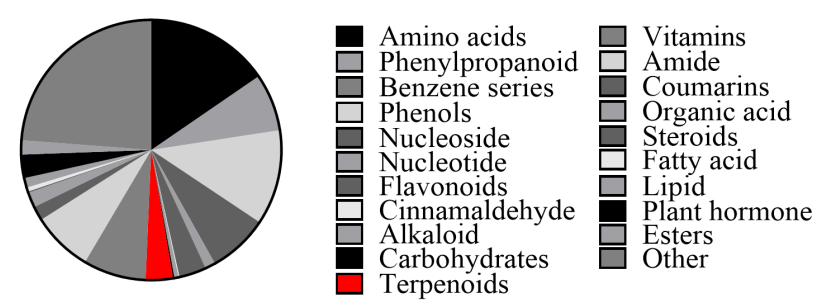

0000000000 0000000000 OOOOOOOOOO $\boldsymbol{m}$ Gibberellin A53 OOO0000000 ㅁ Glutinosone ص Plaunol B 口uillaic acid 0000000000 a Geniposide 0000000000 a Medicagenic acid 0000000000 ש p-Cymene 0000000000
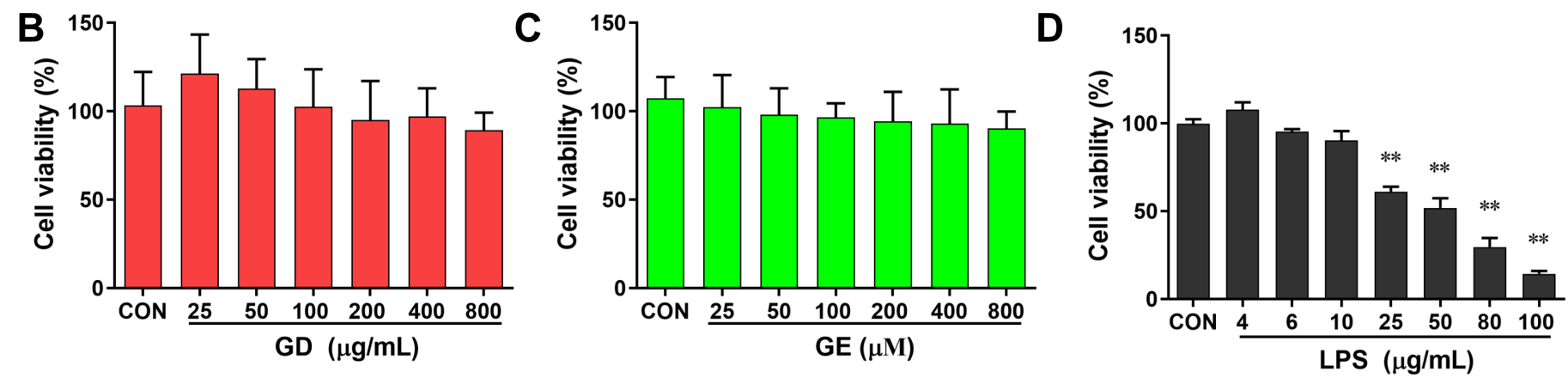

\section{Figure 1}

Effect of Ge on IEC- 6 cell viability. (A) Ge content and structure in GD. (B) An MTT assay was performed to determine the effects of GD on IEC-6 cell viability. (C) An MTT assay was performed to determine the effects of GE on IEC-6 cell viability. (D) An MTT assay was performed to determine the effects of LPS on IEC-6 cell viability. Treatment with GE at concentrations up to $800 \mu \mathrm{M}$ did not significantly decrease the number of viable cells. ${ }^{*} \mathrm{P}<0.05$, ${ }^{\star \star} \mathrm{P}<0.01$ compared with CON. MW: molecular weight; GD: gardenia decoction; GE: geniposide; CON: control; LPS: lipopolysaccharide. 
A
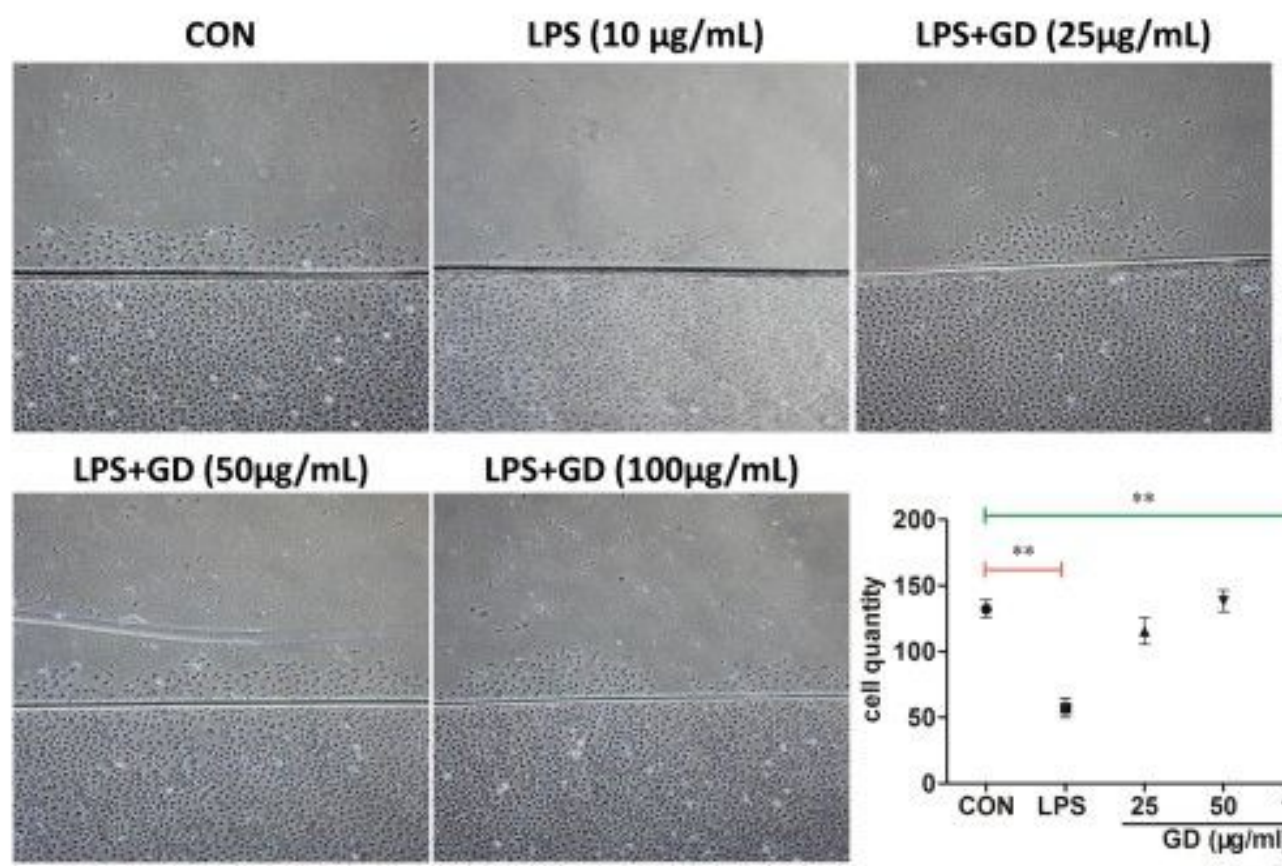

\section{LPS+GD $(100 \mu \mathrm{g} / \mathrm{mL})$}
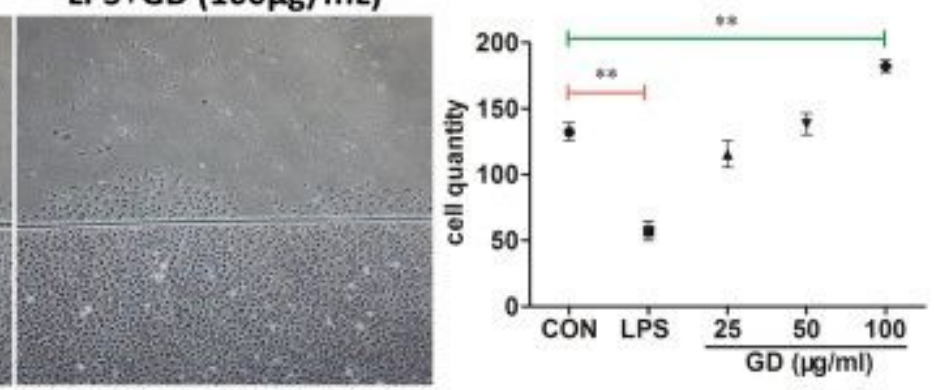

B

CON

LPS $(10 \mu \mathrm{g} / \mathrm{mL})$
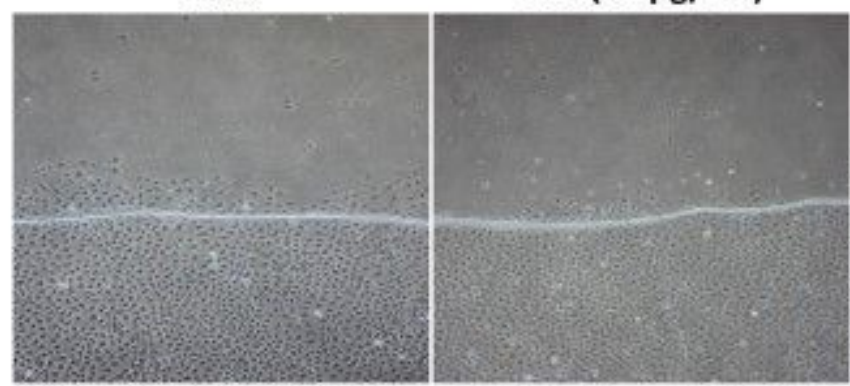

LPS+GE $(25 \mu \mathrm{M})$
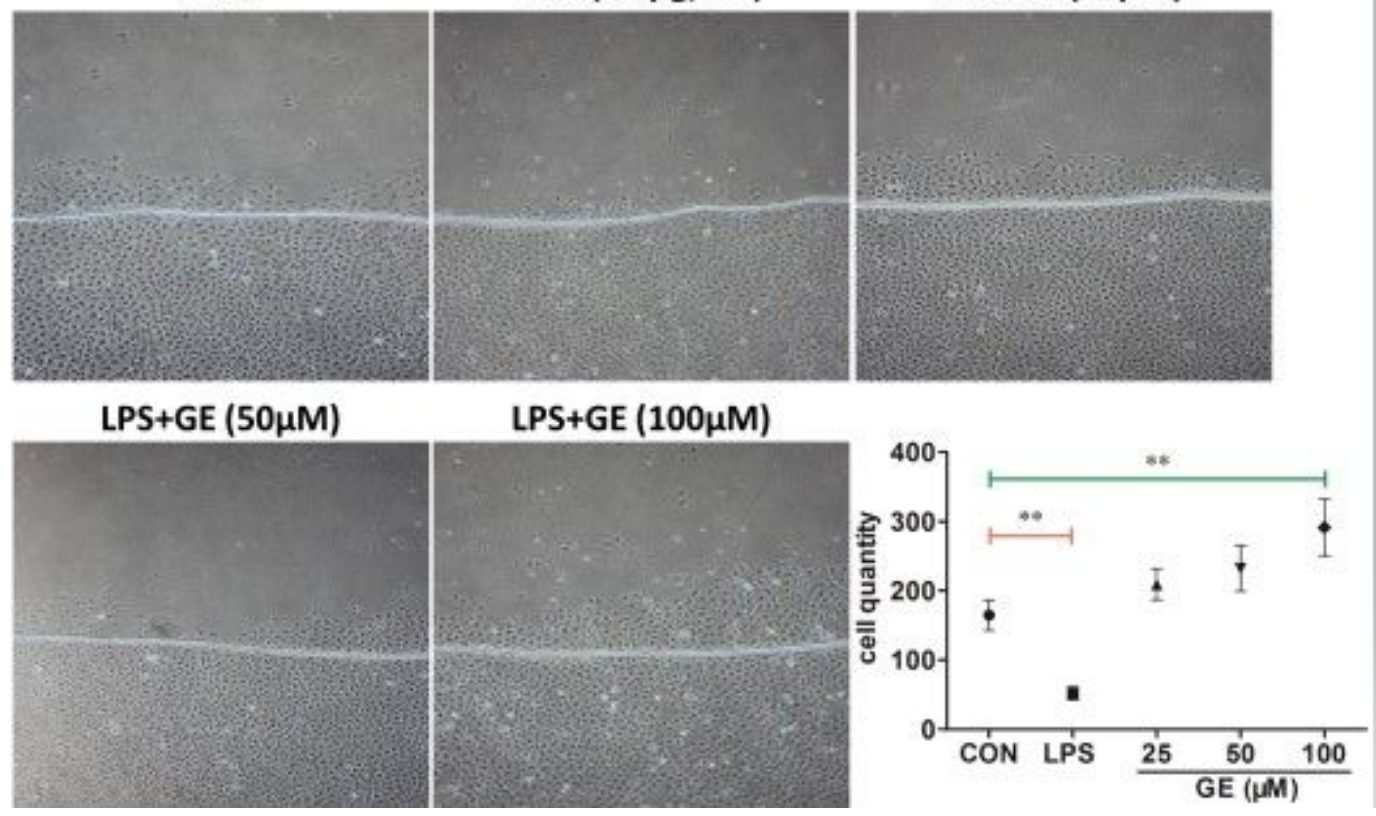

\section{Figure 2}

GE promoted IEC- 6 migration in vitro. (A) Images showing the migration of IEC- 6 cells treated with GD at different concentration in plates. (B) Images showing the migration of IEC-6 cells treated with GE at different concentrations in plates. Migration was quantified as the number of cells in the covered wound area relative to the initial scratched area. Values are presented as the means $\pm S D s(n=8)$. ${ }^{\star \star} P<0.01$ compared with CON. Original magnification, 100x. 
A
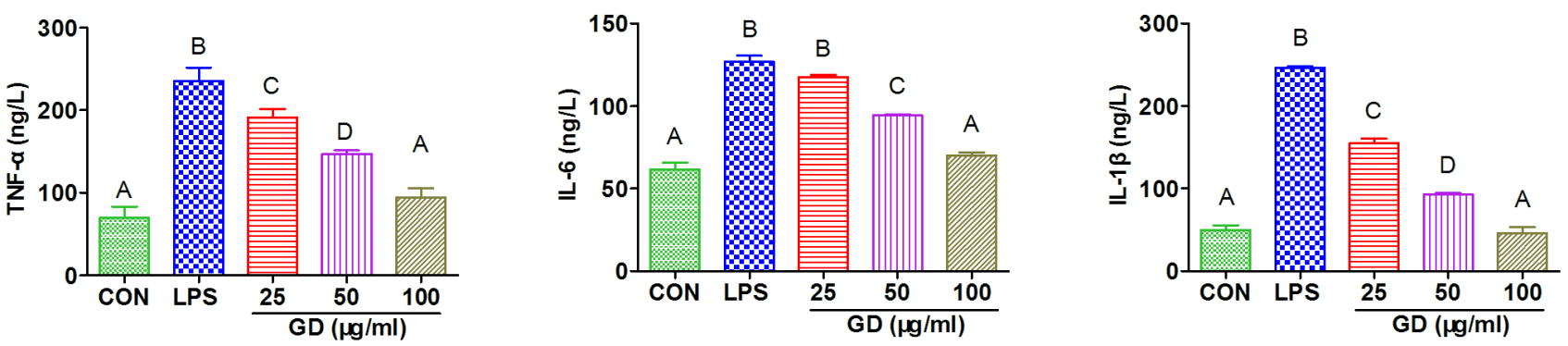

B
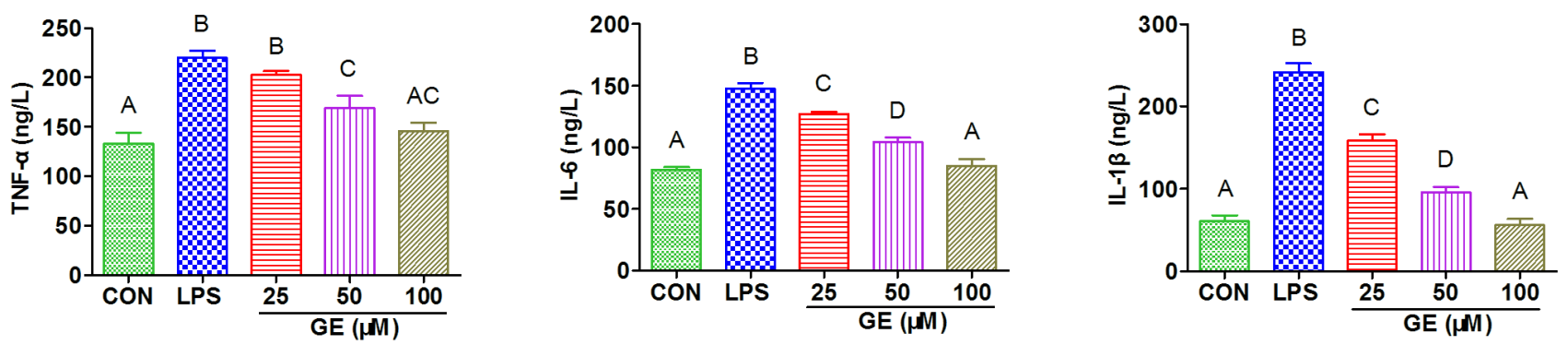

Figure 3

GE inhibited LPS-activated inflammatory cytokines in IEC-6 cells. (A) The effect of GD on the levels of TNF- $\alpha$, IL- 6 , and IL-1 $\beta$ in IEC- 6 cells activated by LPS. A significant decrease in TNF- $\alpha$, IL- 6 , and IL-1 $\beta$ expression was detected in the GD treatment group compared with the LPS model group. (B) The effect of GE on the levels of TNF-a, IL-6, and IL- $1 \beta$ in IEC- 6 cells activated by LPS. A significant decrease in TNF$a, I L-6$, and IL-1 $\beta$ production in the GE treatment group compared with the LPS model group was detected by ELISA. ELISA: enzyme-linked immunosorbent assay; IL: interleukin; LPS: lipopolysaccharide; GD:

gardenia decoction; GE: geniposide; TNF-a: tumor necrosis factor-a. Values from different groups marked with the same letters are not significantly different $(P>0.05)$, and those marked with different letters are significantly different $(P<0.05)$. 


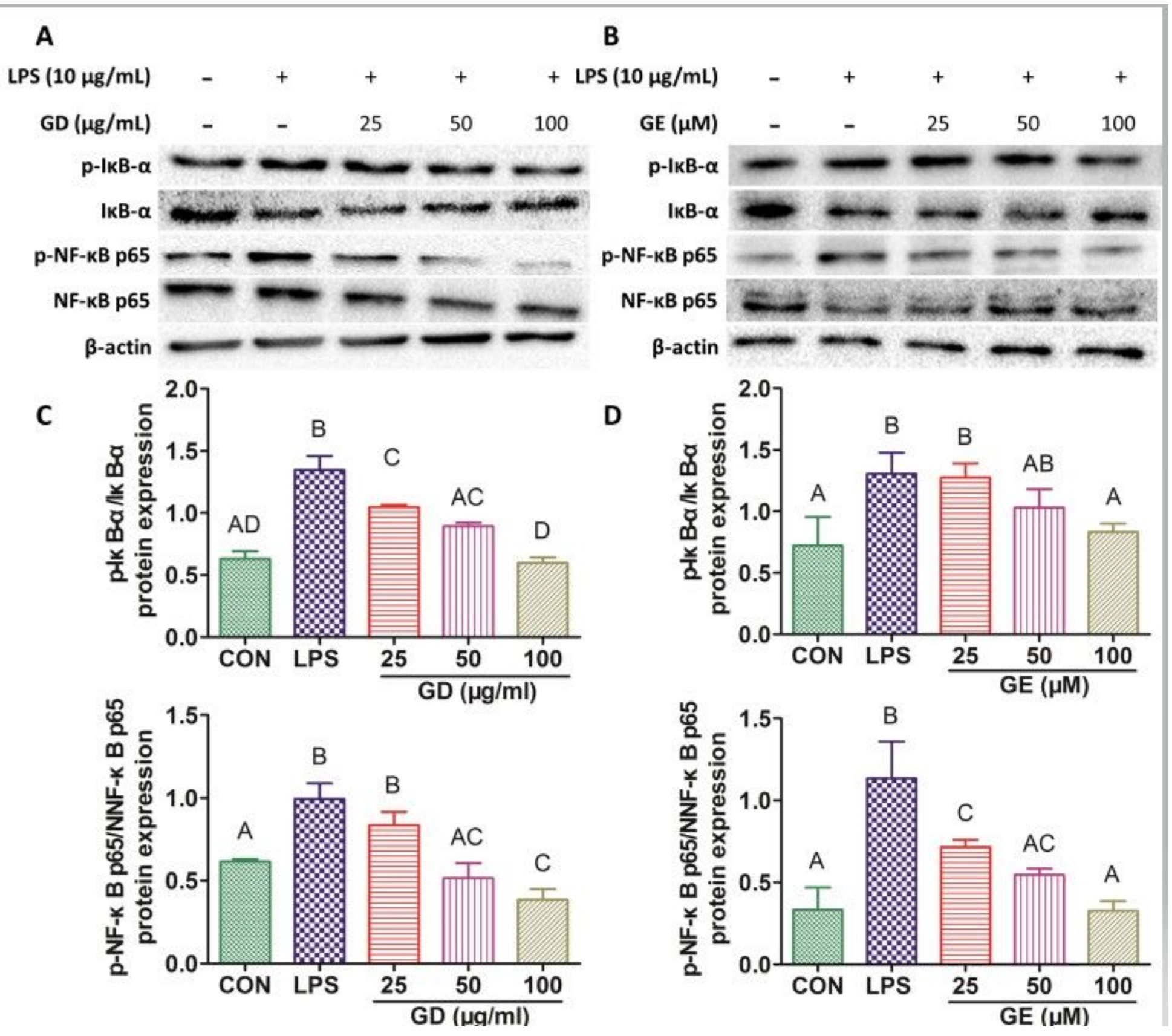

Figure 4

GE inhibited phosphorylation of the NF-KB and IKB-a proteins in IEC- 6 cells activated by LPS. (A, C) Effect of GD on phosphorylation of the NF-KB and IKB-a proteins in IEC- 6 cells, as shown by western blot analysis. (B, D) Expression of LPS activated phosphorylated proteins of NF - $\mathrm{K} B$ and I $\mathrm{K} B$ - $\mathrm{a}$ in IEC-6 cells, as shown by western blot analysis. LPS significantly increased p-NF-kB p65 protein phosphorylation, which was suppressed by GE. Similarly, LPS significantly increased p-IKB-a protein phosphorylation, which was suppressed by GE. LPS: lipopolysaccharide; GD: gardenia decoction; GE: geniposide. Values from different groups marked with the same superscript letters are not significantly different $(P>0.05)$, while those marked with the same letters are significantly different $(P<0.05)$. 


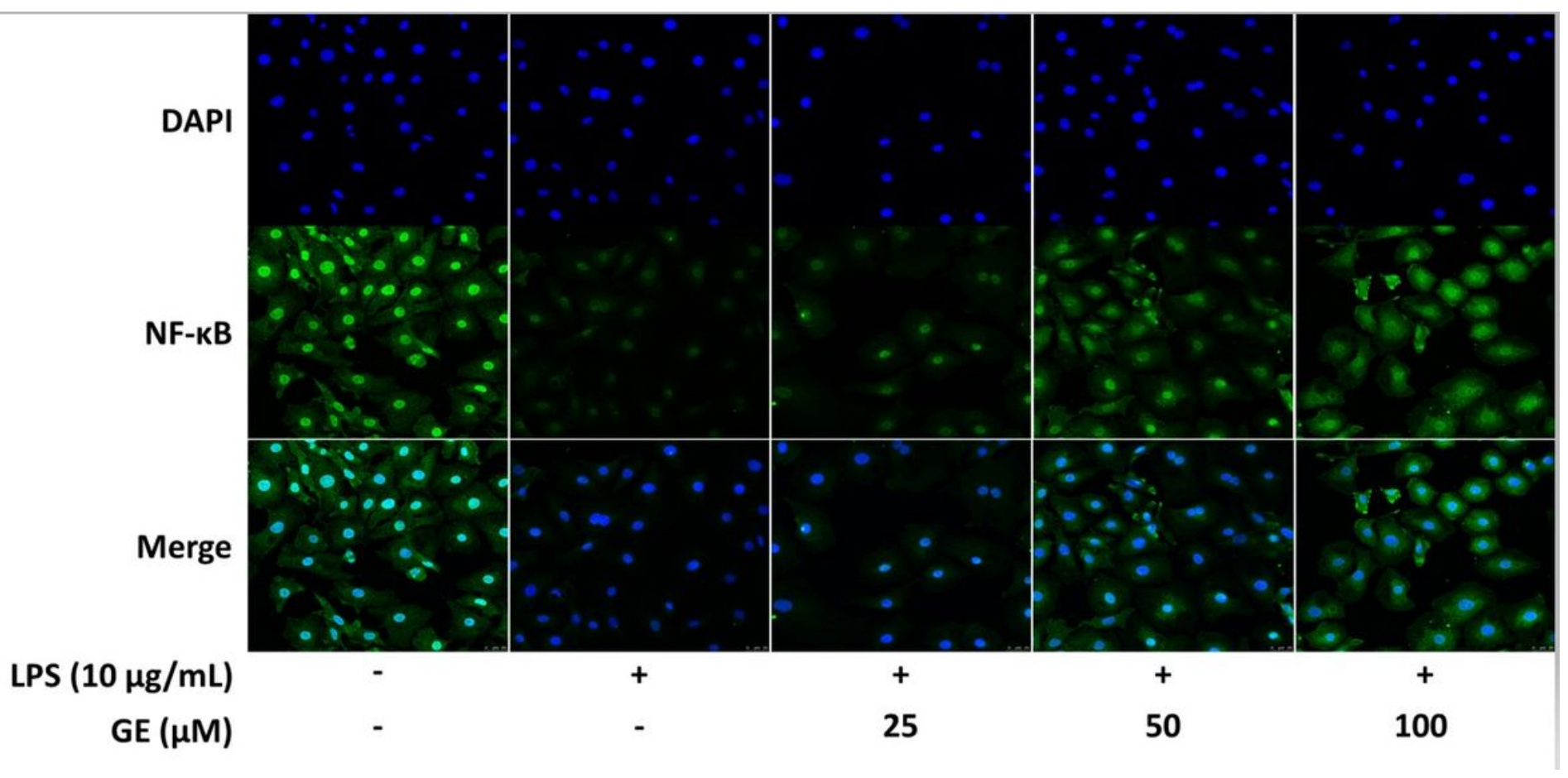

\section{Figure 5}

GE inhibited the LPS-induced translocation of NF-KB. Subcellular localization of NF-KB (green) in IEC-6 cells treated with GE at different concentrations. Nuclei were stained with DAPI (blue). Images (original magnification, 630x) were taken by laser confocal microscopy. 


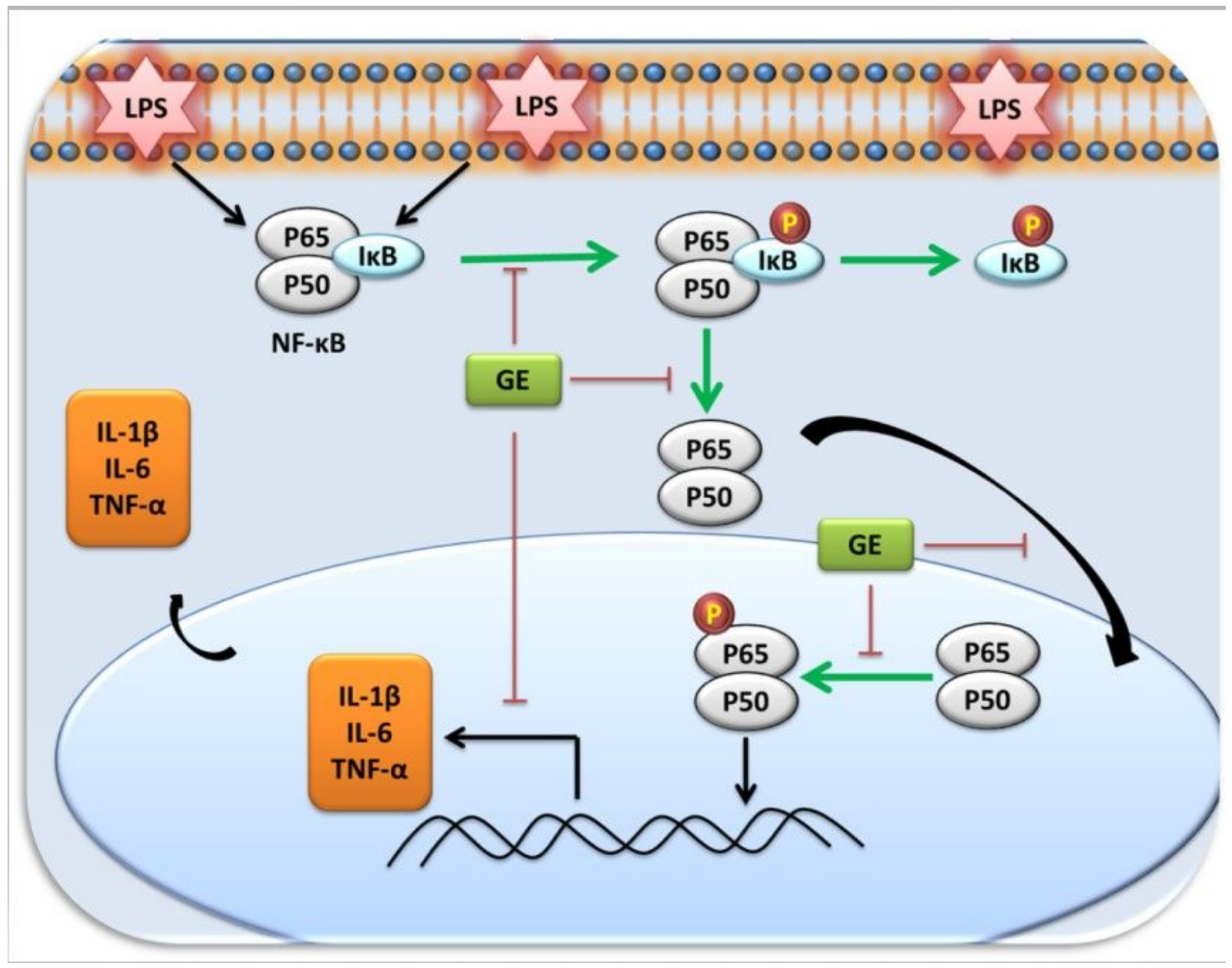

Figure 6

Working model of the effect of GE in vivo. GE suppresses NF-KB signaling pathways and reduces inflammatory cytokine expression in vitro. LPS: lipopolysaccharide; GE: geniposide; NF-KB: nuclear factorKB; IL: interleukin; TNF-a: tumor necrosis factor-a. 